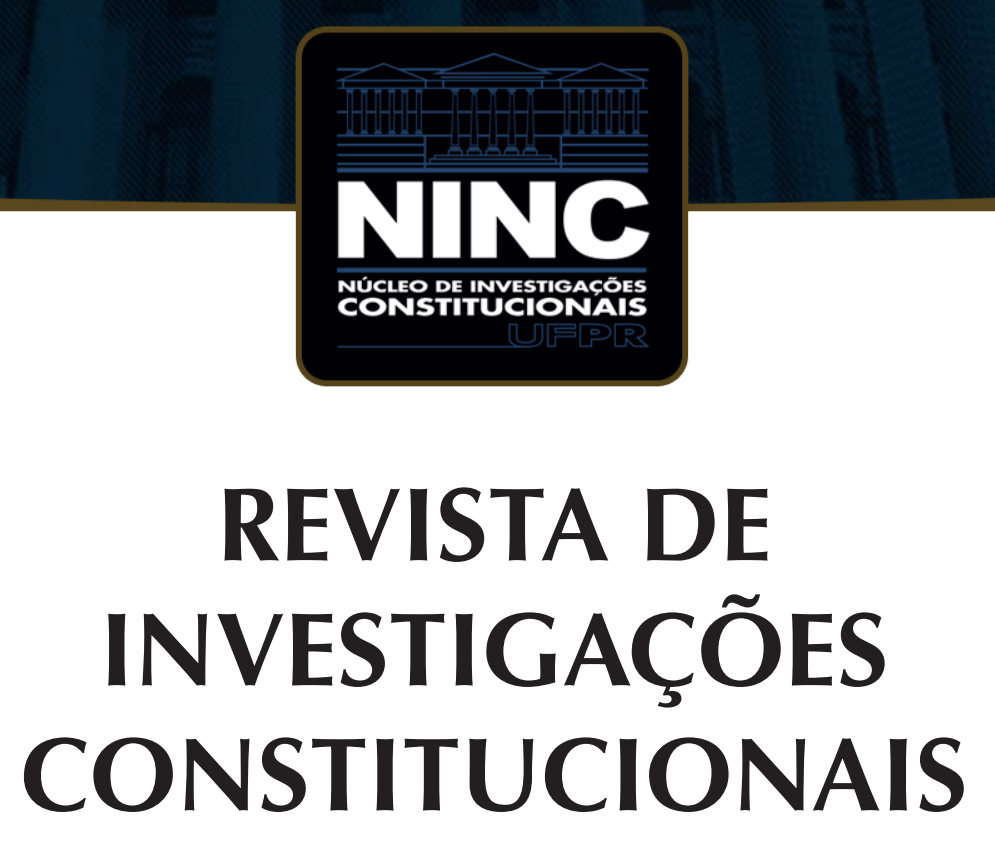

JOURNAL OF CONSTITUTIONAL RESEARCH

vol. 7 | n. 2 | maio/agosto 2020 | ISSN 2359-5639 | Periodicidade quadrimestral Curitiba | Núcleo de Investigações Constitucionais da UFPR | www.ninc.com.br 


\title{
A governabilidade de exceção permanente e a política neoliberal de gestão dos indesejáveis no Brasil
}

\section{The governability of permanent exception and the neoliberal policy of management of the undesirable in Brazil}

\author{
PEDRO ESTEVAM ALVES PINTO SERRANO ${ }^{1, *}$ \\ I Pontifícia Universidade Católica de São Paulo (São Paulo, São Paulo, Brasil) \\ pedroadv@uol.com.br \\ https://orcid.org/0000-0002-2053-3117 \\ RENATA POSSI MAGANE II, ** \\ " Faculdade de Direito de São Bernardo do Campo (São Bernardo do Campo, São Paulo, Brasil) \\ renatapossi@rocketmail.com \\ https://orcid.org/0000-0002-3632-1039 \\ Recebido/Received: 28.06 .2019 / June $28^{\text {th }}, 2019$ \\ Aprovado/Approved: $28.10 .2020 /$ October $28^{\text {th }}, 2020$
}

\section{Resumo}

Temos estudado e observado o fenômeno do autoritarismo estatal nas democracias contemporâneas latino-americanas no século XXI há algum tempo, sobretudo a partir dos golpes de Estado perpetrados contra governos legitimamente e democraticamente eleitos, a exemplo do ocorrido em Honduras, Paraguai e Brasil, nesse último, com a decretação do impeachment da Presidenta Dilma Rousseff em 2016, denunciando o papel que o
Abstract

We have been studying and observing the phenomenon of state authoritarianism in contemporary Latin American democracies in the 21st century for some time, especially since the coups d'état perpetrated against the legitimately and democratically elected governments, as occurred in Honduras, Paraguay and Brazil, in the latter, upon the impeach of President Dilma Rousseff in 2016, denouncing the role that the Criminal Justice System played as a producer of these

Como citar esse artigo/How to cite this article: SERRANO, Pedro Estevam Alves; MAGANE, Renata Possi. A governabilidade de exceção permanente e a política neoliberal de gestão dos indesejáveis no Brasil. Revista de Investigações Constitucionais, Curitiba, vol. 7, n. 2, p. 517-547, maio/ago. 2020. DOI: 10.5380/rinc.v7i2.67686.

" Professor da Pontifícia Universidade Católica de São Paulo (São Paulo-SP, Brasil). Possui pós-doutorado em Teoria Geral do Direito pela Faculdade de Direito da Universidade de Lisboa. Doutor e Mestre em Direito do Estado pela Pontifícia Universidade Católica de São Paulo. Graduado em Direito pela Pontifícia Universidade Católica de São Paulo. Advogado. E-mail: pedroadv@ uol.com.br.

** Professora de Ciência Política e Teoria do Estado, na Faculdade de Direito de São Bernardo do Campo (São Bernardo do Campo-SP, Brasil). Doutoranda em Filosofia do Direito pela Pontifícia Universidade Católica de São Paulo. Mestre em Direito do Estado pela Pontifícia Universidade Católica de São Paulo. Graduada em Direito pela Pontifícia Universidade Católica de São Paulo. Advogada. E-mail: renatapossi@rocketmail.com. 
Sistema de Justiça Criminal desempenhou como agente produtor dessas medidas em que o Judiciário ao invés de corrigir as ilegalidades cometidas, legitimou, por meio da construção de retóricas meramente performáticas, verdadeiros "golpes" perpetrados contra a democracia desses países. Este artigo tem como objetivo ampliar a abordagem de análise do fenômeno do autoritarismo estatal a fim de comprovar que a estratégia adotada nos casos mencionados, mais do que meras distorções e aporias ocasionais, constitui-se em fraude institucionalizada e verdadeira técnica de governabilidade de exceção permanente que se utiliza das leis e das autoridades democráticas para perpetrar inadmissível corrupção sistêmica e impor um Estado autoritário, permitindo a gestão e eliminação dos indesejáveis, dentro do que se convencionou denominar "racionalidade neoliberal".

Palavras-chave: Estado de exceção; governabilidade de exceção permanente; autoritarismo; neoliberalismo; golpes democráticos. measures in which the Judiciary, instead of correcting the illegalities committed, legitimized, through the construction of pure performative rhetoric, true "coups" perpetrated against the democracy of these countries. This article aims to broaden the approach of the analysis of the state authoritarianism's phenomenon in order to prove that the strategy adopted in the mentioned cases, rather than mere distortions and occasional aporias, constitutes an institutionalized fraud and true governance technique of permanent exception which uses laws and democratic authorities to perpetrate systemic corruption and impose an authoritarian State, allowing the management and elimination of the undesirables, within what has been conventionally named "neoliberal rationality".

Keywords: State of exception; governability of permanent exception; authoritarianism; neoliberalismo; democratic coups

\section{SUMÁRIO}

1. Introdução; 2. O neoliberalismo e a desigualdade social como substrato às medidas de exceção;

3. Conclusões; 4. Referências.

\section{INTRODUÇÃO}

Com o fim da 2a Guerra Mundial e o surgimento das legislações e organismos internacionais de proteção aos direitos humanos que se universalizaram e adentraram aos ordenamentos jurídicos internos por meio de constituições rígidas, consubstanciando-se em verdadeiras "sementes anti-fascistas", expressão cunhada por Luigi Ferrajoli, não há mais como se sustentar juridicamente os mecanismos clássicos de combate ao inimigo nacional, seja ele o comunista, os judeus, os negros ou qualquer tipo de existência real que impeça a concretização do discurso hegemônico da ordem, do nacionalismo e da pureza racial, como lamentavelmente assistimos no século passado, em alguns países.

Com a impossibilidade de se sustentarem juridicamente as atrocidades perpetradas pelos Estados de exceção clássicos presentes no século XX, a exemplo do nazismo alemão, fascismo italiano e das ditaduras militares instauradas na América Latina, entre outros modelos autoritários que existiram no período histórico referido, os campos de concentração e extermínio de corpos físicos indesejáveis passaram a ser substituídos no século XXI por uma construção que se opera no campo discursivo, muito mais sofisticado e de difícil constatação, mas que assumem uma potência altamente lesiva para quem a arma da manipulação legal é apontada: um tiro de arbitrariedades 
certeiro que destrói se não fisicamente, simbolicamente a existência do outro, o inimigo declarado, a quem é negada a condição de pessoa e os direitos a ela inerentes pela simples condição de sê-lo.

O mecanismo descrito acima tem sido adotado no Brasil na contemporaneidade pelo Sistema de Justiça com amplo apoio midiático e popular, cuja função precípua e indispensável é a de disseminar esta forma especial de construção discursiva de falseamento da realidade que não apenas legitima as práticas adotadas, como também acirra as disputas ideológicas na construção do ódio como política no seio social e resgatando a lógica binária do amigo/inimigo e da supressão ou morte simbólica dos indesejáveis.

Temos sistematicamente denunciado desde 2007 e mais recentemente em obra publicada em 2016 a ocorrência de"medidas de exceção no interior das sociedades democráticas" ou a presença de uma "governabilidade de exceção permanente", cujas práticas ocorrem na atualidade sem a adoção da suspensão da ordem jurídica vigente, mas como técnica ocasional de governo em que há dois modelos de Estado convivendo simultânea e paralelamente: um Estado de direito formalmente democrático previsto na Constituição Federal e acessível apenas aos economicamente incluídos e politicamente convenientes e um Estado de exceção real presente nas práticas político-jurídicas adotadas contra os inimigos declarados pelos detentores do poder, que são escolhidos ao sabor das necessidades do momento para a manutenção do establishment.

Apresentaremos nesse artigo nossas reflexões mais recentes acerca das características político-econômicas como fenômeno mundial que criam o substrato ideal para instalação do que chamamos de "governabilidade de exceção permanente" para a população excluída (o inimigo pobre) e adoção de medidas de exceção com fim eminentemente político (o inimigo corrupto), por meio, principalmente, da subversão do sistema de persecução penal pelos atores envolvidos no Sistema de Justiça Criminal.

Nesta senda, apresentamos a política neoliberal e a transformação do capitalismo industrial em financeiro, com o consequente aumento da desigualdade social, como fatores que impõem uma governabilidade de exceção permanente contra a parcela excluída da sociedade e mecanismos adotados com finalidade política, dirigidos, sobretudo, aos governos e líderes de esquerda contrários aos interesses do mercado, propugnando-se uma verdadeira criminalização da política a fim de que o controle político seja realizado pelo poder econômico, numa prática muito efetiva de gestão dos indesejáveis.

Na perspectiva lógica da imposição de uma política neoliberal que se impõe no atual cenário político brasileiro, o poder político passa necessariamente a ser subjugado

\footnotetext{
SERRANO, Pedro Estevam Alves Pinto. Autoritarismo e golpes na América Latina: breve ensaio sobre jurisdição e exceção. São Paulo: Alameda, 2016.
} 
ao poder econômico, cujo sistema capitaneado pelo capital financeiro clama pelo autoritarismo e punitivismo estatal como instrumento de garantia das grandes operações do mercado e para conter a violência gerada pelo aumento da desigualdade social que resulta inexoravelmente desse modelo econômico excludente.

Desigualdade esta, aliás, que se agiganta como consequência intrínseca ao atual estágio do capitalismo que não mais depende da força de trabalho operária, indispensável na fase do capitalismo eminentemente industrial, mas do fetiche mercadológico e fantasmagórico que produz riqueza a partir da retroalimentação do próprio capital financeiro e da acumulação de bens concentrada nas mãos de meia dúzia de oligarquias familiares que detém o controle destes novos mecanismos especulativos, seja em mesas de negociações virtuais ou na imprensa, por exemplo, e do locus político para manter as engrenagens da estrutura de poder funcionando perfeitamente ao atendimento dos seus próprios interesses e gerando, nesse sentido, um contingente de pessoas descartáveis e marginalizadas, suscetível a toda sorte de violência e negação de sua condição de cidadania.

Se por um lado esse sistema de mercado demanda a presença de um Estado forte e dilatado, por outro, exige a redução, e até mesmo a suspensão, dos direitos dos indivíduos, apresentando-se, portanto, autoritário por excelência, desmistificando-se a ideia de um Estado mínimo associado ao modelo do capitalismo pós-industrial, pois, paradoxalmente, o mercado de capital de cariz eminentemente financeiro exige um Estado autoritário, máximo, a seu serviço.

Não à toa que países que adotaram o modelo neoliberal (a exemplo da Inglaterra de Margareth Tatcher e países latino-americanos que a partir da década de 90 adotaram a cartilha impositiva do Consenso de Washington, como Argentina, Brasil, Uruguai, Paraguai, Chile, Bolívia, Equador, Venezuela e Colômbia), aumentaram os custos estatais com o aparelho repressivo, superando os investimentos sociais do Estado de Bem Estar Social, caindo por terra a falaciosa promessa de redução de gastos públicos.

Essa apontada tendência à unificação dos poderes como mecanismo de manutenção dos privilégios do mercado de capital é, sem sombra de dúvida, a principal causa da ruptura democrática percebida nos últimos anos e que tem provocado o desmonte das conquistas sociais alcançadas nas últimas décadas de governos petistas, recolocando milhões de pessoas novamente na condição de pobreza extrema, conforme dados medidos pelo Sistema de Indicadores Sociais (SIS) e divulgados pelo Instituto Brasileiro de Geografia e Estatísticas (IBGE), com dois milhões a mais de pessoas retornando a essa condição de miserabilidade entre 2016 e $2017^{2}$.

\footnotetext{
Disponível em: <https://agenciadenoticias.ibge.gov.br/agencia-sala-de-imprensa/2013-agencia-de-noticias/releases/23298-sintese-de-indicadores-sociais-indicadores-apontam-aumento-da-pobreza-entre-2016-e-2017>. Acesso realizado em 08/03/2019.
} 
A separação entre poder econômico e poder político que marca a ascensão da democracia liberal é subvertida pela "racionalidade neoliberal" que avança como fenômeno globalizante a partir dos anos 80 do século passado, e, particularmente no Brasil, a partir dos anos 90 .

Questões como encarceramento em massa, seletividade da punição criminal, desrespeito aos direitos e garantias penais e processuais penais, espetacularização e condenação midiática, hipernomia e apropriação privada da linguagem pelos aplicadores do direito e dos agentes como um todo que compõem o Sistema de Justiça Criminal (Poder Judiciário, Ministério Público, Polícia, etc.), são, grosso modo, os principais fenômenos observados nessa técnica de gestão dos indesejáveis dentre da lógica da política neoliberal.

A ampliação do direito penal como instrumento de controle social, flexibilizando ou mesmo subtraindo os direitos do acusado - ou daquele que é perseguido pela justiça penal -, ocorre em várias partes do mundo por diferentes razões.

Contudo, importante anotar que a política de encarceramento em massa adotada no âmbito do neoliberalismo a partir do início da década de 90 no Brasil, e que propiciou esse aumento desenfreado da população carcerária, não foi acompanhado da diminuição dos crimes considerados violentos nem tampouco da diminuição da sensação de insegurança. Com população de 726 mil presos e a terceira maior do mundo ${ }^{3}$, atrás apenas dos Estados Unidos e China, não vimos o índice de violência regredir, o que contraria o discurso do encarceramento e punitivismo como política de segurança pública eficaz contra o aumento da criminalidade.

Importante salientar que esses mecanismos que descrevemos como medidas de exceção adotadas concomitantemente na rotina democrática, sem suspensão da ordem jurídica vigente, operam-se de formas distintas nos contextos de países mais desenvolvidos, a exemplo da Europa e Estados Unidos, onde se tem, grosso modo, a edição de atos do Legislativo - por meio de normas gerais e abstratas - que fortalecem o Executivo, a exemplo das leis anti-terroristas, como o patrioct act e a admissão de um direito penal especial direcionado aos estrangeiros suspeitos de cometimento de supostos crimes de terrorismo atentatórios à segurança nacional.

Nos países de capitalismo periférico e desiguais da América Latina, as medidas de exceção são direcionadas ao inimigo interno, que pode ser tanto o bandido (parcela pobre, majoritariamente negra e marginalizada da sociedade), como o corrupto. Nesse último caso, por meio do Sistema de Justiça que atua a serviço dos interesses do mercado e opera para criminalizar lideranças de esquerda, a exemplo dos processos penais e prisões adotadas no contexto da Operação Lava-Jato e que mantem preso por meio

3 Segundo dados extraídos do INFOPEN (Relatório de Informações Penitenciárias), disponível em <http:// www.justica.gov.br/noticias/ha-726-712-pessoas-presas-no-brasil/relatorio_2016_junho.pdf>, acesso realizado em 03/13/2019. 
de ilações e condutas não comprovadas o maior líder político da esquerda brasileira, o ex-Presidente Lula.

Neste sentido, com relação à parcela da população incluída surgem essas medidas de exceção com finalidade política em duas modalidades: a) impeachment e golpes de Estado de presidentes democraticamente eleitos; b) processos penais de exceção e persecução de líderes políticos, em geral de esquerda.

Na América Latina, golpes militares clássicos como os ocorridos no Brasil, na Argentina e no Chile, são um fenômeno do século XX que ficaram para trás. No século $\mathrm{XXI}$, estabeleceu-se no mundo ocidental um forte consenso democrático, ou seja, consolidou-se um discurso de legitimação da democracia como valor universal.

Entretanto, isso não significa que o autoritarismo deixou de existir no interior dos Estados democráticos. As medidas autoritárias apenas passaram a ser revestidas de uma aparência de legitimidade democrática, sem interdição declarada da ordem jurídica.

O impeachment da Presidenta Dilma Rousseff em 2016 foi mais uma faceta dessas medidas de exceção que, sem qualquer fundamentação juridicamente plausível, interrompe ilícita, inconstitucional e agressivamente um mandato legítimo, suprimindo a soberania popular e o direito político de mais de 54 milhões de pessoas, esvaziando, assim, a democracia.

Importante ressaltarmos que o Judiciário tem atuado nesses processos como legitimador dos golpes institucionais perpetrados, pois embora o Supremo Tribunal Federal tenha determinado as regras do processo de impeachment, não se pronunciou até hoje sobre as medidas que contestam o processo e suas flagrantes ilegalidades.

Não há dúvidas de que no caso do impeachment da Presidenta Dilma, mais do que uma inconstitucionalidade, o que por si só já seria de uma gravidade tamanha, fora utilizada uma interpretação dos fatos à luz de uma manipulação do texto legal a fim de interromper o ciclo democrático e implementar um projeto que atendesse única e exclusivamente os interesses da elite econômica dominante, o que se confirmou com a concretização da reforma trabalhista e a PEC do teto de gastos públicos, particularmente no tocante aos investimentos em áreas sociais, aprovadas sem qualquer dificuldade logo em seguida à destituição da Presidenta.

Ao lado dos mecanismos de interrupção dos ciclos democráticos por meio de impeachments inconstitucionais e golpes perpetrados contra governos principalmente de esquerda, vem ocorrendo também na contemporaneidade a criminalização dos agentes políticos seletivamente selecionados por não representarem os interesses e privilégios do mercado

Nesse sentido, o sistema de justiça criminal, composto por vários agentes estatais (Poder Judiciário, Ministério Público, Delegados, Polícia, etc.), com o apoio 
fundamental da mídia ${ }^{4}$, torna-se o autor soberano das medidas de exceção, instaurando-se indubitavelmente uma guerra legal contra os indesejáveis, realidade que tem atingido os setores mais resistentes aos desmandos que já se observam no governo Bolsonaro, como os movimentos sociais, as universidades públicas e as minorias organizadas, tais como LGBTQ, feministas, negros, índios, entre outros.

Isso implica trazer o regime jurídico próprio da guerra para o plano interno, tomando parcela da sociedade como inimiga e retirando daqueles que fazem parte desse grupo a condição humana que Ihes confere proteção política e jurídica, por meio da desconstrução midiática da sua imagem e da sua dignidade.

Embora muitas vezes a exceção se empregue a partir de mecanismos jurídicos, a motivação é sempre política e sua adoção justificada pela emergência, no aspecto temporal, e insegurança no campo social e axiológico. O conceito de exceção pressupõe ainda que os direitos próprios da democracia liberal são adequados para reger a normalidade cotidiana.

É na excepcionalidade, ou seja, numa situação em que o Estado se vê ameaçado pelo inimigo, que esses direitos podem ser suspensos - semelhante ao que ocorre em relação ao estado de sítio no Brasil e o estado de guerra na Inglaterra. Mas a suspensão não ocorre mais de forma declarada ou autorizada pela ordem constitucional, mas por meio de interpretações legais inconstitucionais por autoridades que têm junto à população em geral uma credibilidade a partir da crença generalizada da neutralidade e distanciamento dos interesses político-partidários, substituindo-se as botas do militar pela toga do magistrado e a arma pela lei como instrumento do verdadeiro lawfare contemporâneo brasileiro.

\section{O NEOLIBERALISMO E A DESIGUALDADE SOCIAL COMO SUBS- TRATO ÀS MEDIDAS DE EXCEÇÃO}

O aumento das medidas de exceção no interior das sociedades democráticas sem a adoção da suspensão da ordem vigente a partir principalmente dos anos

\footnotetext{
4 "Hoje é impossível pensar o funcionamento do Sistema de Justiça Criminal sem analisar o funcionamento dos meios de comunicação de massa, que produzem hipóteses acusatórias, selecionam 'provas', julgam (sem os limites impostos pelas constituições democráticas) e executam pessoas diante de seus leitores, ouvintes e espectadores. Não raro, os julgamentos e execuções midiáticas são mais céleres e festejados do que aqueles realizados pelo Poder Judiciário. Não raro, os julgamentos midiáticos influenciam os julgamentos do Poder Judiciário, isso porque muitos juízes também querem ser festejados pelos meios de comunicação de massas." In: CASARA, Rubens R. R. Estado pós-democrático: neo-obscurantismo e gestão dos indesejáveis. Rio de Janeiro: Civilização Brasileira, 2017, p. 99-100.

5 O termo lawfare, formado pela junção das palavras law, "lei" e warfare, "guerra", foi empregado pela primeira vez em 1970 e disseminado pelo coronel da Força Aérea dos EUA, Charles Dunlap em 2001, utilizado para expressar o fenômeno da guerra jurídica adotado em substituição à guerra armada em que a lei era manipulada como arma de guerra com a intenção de controlar, perseguir e exterminar os opositores políticos, por meio de manobras jurídicas ilegítimas, mas com aparência e verniz de legitimidade e legalidade.
} 
sessenta e setenta do século passado, decorre, inegavelmente, da formação de uma nova fase do capitalismo, que deixa de ser predominantemente industrial e se torna indubitavelmente financeiro.

Um sistema capitaneado pelo capital financeiro, com apoio tecnológico e militar, em que a presença do autoritarismo estatal torna-se fundamental instrumento de garantia tanto para a segurança das operações financeiras dos grandes grupos econômicos (há uma credibilidade nas suas instituições, pois o Estado torna-se o garantidor dessas operações em última instância - uma espécie de "mão invisível do Estado"), bem como para conter a violência gerada pelo aumento da desigualdade social, consequência intrínseca do atual estágio do capitalismo.

Se por um lado esse sistema de mercado demanda a presença de um Estado forte e dilatado, por outro, exige a redução - e até mesmo a suspensão - dos direitos dos indivíduos, apresentando-se, portanto, autoritário por excelência. Há nesse ponto que se desmitificar a ideia de um Estado mínimo associado ao modelo do capitalismo pós industrial, pois o mercado de capital de cariz eminentemente financeiro exige um Estado autoritário, máximo, a seu serviço.

Sob esse aspecto, Rafael Valim em trabalho fundamental intitulado "Estado de Exceção: a forma jurídica do neoliberalismo" ${ }^{6}$, afirma que "à impotência da política perante a economia deve corresponder um aumento de sua potência em relação à sociedade", e rememora ainda as palavras de Leymert Garcia para quem o mercado "precisa, evidentemente, de um Estado fraco como instância de decisão e formulação de política, mas forte como organismo gestor de população e dispositivo de controle social" ${ }^{\prime \prime}$.

Isso ocorre, a nosso ver, por duas razões: primeiro, diante do dinamismo do mercado econômico e pelo risco que a evasão da fortuna das grandes instituições financeiras ocasionaria à estabilidade política, ocorre uma inversão no modelo de centralização do poder: o poder político passa a ser controlado pelo poder econômico e o Estado torna-se o garantidor das grandes operações do mercado; segundo, como a acumulação de riqueza produzida pelo sistema capitalista gera inevitavelmente uma grande desigualdade social, exige-se cada vez mais o aumento do autoritarismo e punitivismo estatal a fim de conter o produto desse abismo social, a violência.

\footnotetext{
6 VALIM, Rafael. Estado de exceção: a forma jurídica do neoliberalismo. São Paulo: Editora Contracorrente, 2017.

7 VALIM, Rafael. Estado de exceção: a forma jurídica do neoliberalismo. São Paulo: Editora Contracorrente, 2017, p. 31.
} 
Alinhado com as nossas premissas apresentadas, Rubens Casara em obra fundamental recém publicada ${ }^{8}$, ao denunciar o que chama de Estado Pós-Democrático ${ }^{9}$, nos faz o seguinte alerta:

Ao contrário do que sustentam os discursos de viés liberal dos que estão satisfeitos com o Estado Pós-Democrático, não há diminuição da intervenção estatal na vida da sociedade. Em outras palavras, o cidadão não se viu livre da opressão e do arbítrio estatal. Por outro lado, o Estado Pós-Democrático revela-se um Estado forte e com tendências arbitrárias, possivelmente o Estado menos sujeito a controle desde a criação do Estado Moderno. A pós-democracia é um modelo estatal aberto a novos despotismos, no qual se permite tanto a concentração de poderes quanto a existência daquilo que Luigi Ferrajoli chamou de 'poderes selvagens,' poderes sem limites. ${ }^{10}$

Na criminologia há um consenso de que a desigualdade social é o principal fator desencadeador da violência. Sociedades extremamente desiguais geram muita violência. Um país pode ser pobre e pouco violento ou rico e pouco violento, mas, se é desigual, convive com alto índice de violência e repressão estatal.

Não à toa, Alessandra Teixeira, em sua tese de doutorado, cuja publicação foi intitulada como "Prisões da exceção: política penal e penitenciária no Brasil contemporâneo", obra indispensável para aprofundamento do debate das medidas de exceção no campo da criminologia, ao descrever os impactos do neoliberalismo para o crescimento da desigualdade social e aumento da violência, constata:

Mas foi, sobretudo, a prevalência de uma política econômica calcada nos ditames do mercado, em que o alcance das metas fiscais conseguidas a partir de altos juros e absoluta compressão orçamentária em nome de vultosos 'superávits primários,' pôde redesenhar, não obstante as previsões da Constituição de 1988, o papel do Estado na distribuição da riqueza social e, assim do tratamento da

\footnotetext{
8 CASARA, Rubens R. R. Estado pós-democrático: neo-obscurantismo e gestão dos indesejáveis. Rio de Janeiro: Civilização Brasileira, 2017.

9 “Por 'Pós-Democrático', na ausência de um termo melhor, entende-se um Estado sem limites rígidos ao exercício do poder, isso em um momento em que o poder econômico e o poder político se aproximam, e quase voltam a se identificar, sem pudor. No Estado Pós-Democrático a democracia permanece, não mais com um conteúdo substancial e vinculante, mas como mero simulacro, um elemento discursivo apaziguador. $\mathrm{O}$ ganho democrático que se deu com o Estado Moderno, nascido da separação entre o poder político e o poder econômico, desaparece na pós-democracia e, nesse particular, pode-se falar em uma espécie de regressão pré-moderna, que se caracteriza pela vigência de um absolutismo de mercado." In: CASARA, Rubens R. R. Estado pós-democrático: neo-obscurantismo e gestão dos indesejáveis. Rio de Janeiro: Civilização Brasileira, 2017, p. 22.

10 CASARA, Rubens R. R. Estado pós-democrático: neo-obscurantismo e gestão dos indesejáveis. $1^{\text {a ed. }}$ Rio de Janeiro: Civilização Brasileira, 2017, p. 25-26.
} 
questão social no país, coibindo ainda mais fortemente as possibilidades de realização dos direitos de cidadania a setores mais amplos da sociedade. ${ }^{11}$

Segundo estudo publicado pela OCDE (Organização para a Cooperação e Desenvolvimento Econômico) em maio de 2015, o crescimento da desigualdade de renda entre os países ricos, a exemplo dos EUA, vem suplantando o dos países da América Latina na última década, conforme relatório In it together - Why less inequality benefits all' ${ }^{12}$.

As mudanças ocorridas no mercado de trabalho, decorrentes da globalização, dos avanços tecnológicos e das reformas regulatórias são apontadas pelos analistas econômicos como um dos principais fatores para explicar o crescimento da desigualdade nos países da $O C D E$, que é atualmente composto por 35 países (o Brasil não integra essa lista).

A desigualdade crescente nos países ricos tem relação direta com a mudança do perfil da demanda de trabalho percebida nas últimas três décadas, aumentando a disparidade entre os salários dos que detém um maior nível de qualificação em setores com alta demanda (como tecnologia da informação e finanças) em comparação com os de baixa formação em setores com baixa demanda.

O resultado da pesquisa apontado no relatório da OCDE não surpreende as percepções mais atentas do fenômeno: o capitalismo financeiro não precisa mais de um exército de reserva de mão de obra e um grande contingente de pessoas é destinado a uma não vida social, a uma condição não humana.

Nesta perspectiva, Achille Mbembe aponta o neoliberalismo como o catalizador desse processo: "O neoliberalismo é a época ao longo da qual o tempo (curto) se presta a ser convertido em força reprodutiva da forma-dinheiro. Tendo o capital atingido o seu ponto de fuga máximo, desencadeou-se um movimento de escalada. O neoliberalismo baseia-se na visão segundo a qual 'todos os acontecimentos e todas as situações de mundo vivo (podem) deter um valor no mercado."13

Como razão desse fenômeno que busca, segundo o precitado autor, racionalizar o mundo a partir de lógicas empresariais ${ }^{14}$, "já não há trabalhadores propriamente ditos. Já só existem nómadas do trabalho. Se, ontem, o drama do sujeito era ser explorado pelo capital, hoje a tragédia da multidão é não poder já ser explorada de todo, é ser objecto de humilhação numa humanidade supérflua, entregue ao abandono, que já nem é útil ao funcionamento do capital.."15

\footnotetext{
11 TEIXEIRA, Alessandra. Prisões da exceção: política penal e penitenciária no Brasil contemporâneo. Curitiba: Juruá, 2009, p. 104.

12 Disponível em: <http://www.oecd.org/social/in-it-together-why-less-inequality-benefits-all-9789264235120-en.htm>, acessado em 11/04/2019.

13 MBEMBE, Achille. Crítica da razão negra. Trad. Marta Lança. Lisboa: Antígona, 2014, p. 13.

14 MBEMBE, Achille. Crítica da razão negra. Trad. Marta Lança. Lisboa: Antígona, 2014, p. 13.

15 MBEMBE, Achille. Crítica da razão negra. Trad. Marta Lança. Lisboa: Antígona, 2014, p. 14.
} 
Tais fatores apontados como mudanças de paradigmas na relação do poder e o aumento da violência gerada, sobretudo, pelo aumento da desigualdade social, clamam a presença de um Estado autoritário. Já não há mais propriamente liberdade de mercado, porque não há competição, pois, como afirmamos anteriormente, pelo risco sistêmico existente, o Estado torna-se o principal garantidor das grandes instituições capitalistas e das suas operações e, como o capital circula no mundo de forma muito rápida pelos mecanismos de comunicação global, consegue não só fugir do controle político como passa inclusive a controlá-lo, ocorrendo o fortalecimento e centralização do poder político na mão do capital.

É o que Valim chama de racionalidade neoliberal, ou seja, "um dispositivo de natureza estratégica que propugna uma sociedade individualista, altamente competitiva, cujas pulsões são falsamente satisfeitas através do consumo e cujos juízos são construídos em um ambiente marcado pela espetacularização."16

Por tais razões, corretamente aponta Valim que "quem decide sobre a exceção atualmente é o chamado 'mercado', em nome de uma elite invisível e ilocalizável; é dizer, o soberano na contemporaneidade é o mercado"17, e "em última análise, o estado de exceção é uma exigência do atual modelo de dominação neoliberal. É o meio pelo qual se neutraliza a prática democrática e se reconfiguram, de modo silencioso, os regimes políticos em escala universal."18

Essa apontada tendência à unificação dos poderes como mecanismo de manutenção dos privilégios do mercado de capital é, sem sombra de dúvida, a principal causa da ruptura democrática percebidas nas últimas décadas. Para além da necessária e já conhecida teoria das separações dos poderes de Montesquieu (Executivo, Legislativo e Judiciário), a concretização dos ideários democráticos pressupõe também a separação entre poder político e poder econômico.

Norberto Bobbio, em artigos críticos escritos com a ascensão de Silvio Berlusconi ao cargo de primeiro-ministro da Itália, reunidos sob o título "Contra os novos despotismo: escritos sobre o berlusconismo"19, resgata a teoria do filósofo político americano Michael Walzer em Il liberalismo come arte dela separazione (O liberalismo como arte da separação) para denunciar o perigo que representava à democracia italiana a unificação dos poderes econômico, político e cultural em uma só pessoa.

Neste sentido, assevera o autor italiano:

\footnotetext{
16 VALIM, Rafael. Estado de exceção: a forma jurídica do neoliberalismo. São Paulo: Editora Contracorrente, 2017, p. 32.

17 VALIM, Rafael. Estado de exceção: a forma jurídica do neoliberalismo. São Paulo: Editora Contracorrente, 2017, p. 33.

18 VALIM, Rafael. Estado de exceção: a forma jurídica do neoliberalismo. São Paulo: Editora Contracorrente, 2017, p. 34.

19 BOBBIO, Norberto. Contra os novos despotismos: escritos sobre o berlusconismo. São Paulo: Editora Unesp; Instituto Norberto Bobbio, 2016.
} 
Não há precedentes, em países democraticamente mais maduros do que o nosso, de uma tendência à unificação do poder político com o poder econômico e com o poder cultural - por meio do potentíssimo instrumento da televisão, incomparavelmente superior àquele dos jornais, que, todavia, foram chamados de quarto poder - como aquela que se entrevê no movimento Força Itália. A unificação dos três poderes em um só homem ou em um só grupo tem um nome bem conhecido na teoria política. Chama-se, como denominava Montesquieu, despotismo20.

Embora muito se fale das consequências do neoliberalismo no plano econômico - que, nos países anglo-saxões, significou a desregulamentação das atividades de interesse público, as public utilities, e, na Europa, a transformação de serviços públicos antes sob a responsabilidade do Estado em atividades privadas, porém, regulamentadas -, há uma outra dimensão do Estado neoliberal que precisa ser observada, sobretudo nas Américas: a construção de um Estado autoritário e punitivista.

A ampliação do direito penal como instrumento de controle social, flexibilizando ou mesmo subtraindo os direitos do acusado - ou daquele que é perseguido pela justiça penal -, ocorre em várias partes do mundo por diferentes razões.

Aqui, no continente americano, tal fenômeno está intrinsecamente ligado à adoção do modelo neoliberal. $O$ endurecimento das leis penais e a consequente superlotação das prisões é uma das engrenagens de um sistema que aprofunda a injustiça e a desigualdade e que, a fim de proteger os interesses das classes economicamente incluídas, segrega o pobre, então tipificado como bandido. O Juiz de Direito Rubens Casara, com sapiência notável confirma nossa assertiva, no trecho que segue:

O poder penal é um dos principais instrumentos para o controle social de pessoas indesejáveis aos olhos dos governantes, dos detentores do poder político e do poder econômico. O poder penal, que antes relacionava-se com o mercado de trabalho, em uma quadra histórica na qual a relação entre o cárcere e a fábrica era inegável, uma vez que a pena era vista como uma medida correcional que visava preparar pessoas para a cultura do trabalho, hoje tem a finalidade política de neutralizar os inimigos e atender à razão neoliberal. O neoliberalismo, aliás, percebido como um modo de governar a sociedade, tem que recorrer ao poder penal para sustentar o projeto capitalista. ${ }^{21}$

Como se sabe, na década de 1970, então sob o comando de Nixon, o governo norte-americano iniciou a articulação de um discurso de guerra às drogas que, mais

20 BOBBIO, Norberto. Contra os novos despotismos: escritos sobre o berlusconismo. São Paulo: Editora Unesp; Instituto Norberto Bobbio, 2016, p. 15.

21 CASARA, Rubens R. R. Estado pós-democrático: neo-obscurantismo e gestão dos indesejáveis. Rio de Janeiro: Civilização Brasileira, 2017, P. 93. 
tarde, se intensificou e se traduziu numa política de encarceramento em massa responsável por colocar os Estados Unidos no topo do ranking de aprisionados.

Em apenas dez anos, entre 1980 e 1990, o número de presos saltou de 514 mil para 1,2 milhão e continuou subindo nos anos 2000. Após a sanção da lei penal de 1994, pelo democrata Bill Clinton, o contingente de presos chegou a 2 milhões de pessoas, com predominância de negros e latinos.

A suposta "solução" para combater o tráfico de drogas e garantir maior segurança à sociedade foi importada pelo Brasil, que, da década de 1990 para cá, vimos o número de presos no país aumentar em 707\%, passamos de um contingente de 90 mil presos para mais de 726 mil, num intervalo de 26 anos apenas. Temos hoje a terceira maior população encarcerada do mundo, em termos absolutos, atrás apenas dos Estados Unidos e China,, e a 31ª em números relativos (relação de presos para cada 100 mil habitantes, nos países com população superior a 10 milhões) ${ }^{22}$.

Mais grave do que ocupar a terceira posição é o fato de que caminhamos para a primeira. Contamos com cerca de 726 mil presos e o número de detenções cresce $7,3 \%$ ao ano, segundo dados do último relatório do Sistema Integrado de Informações Penitenciárias (Infopen) medidos até julho de 2016 e divulgado em $2017^{23}$. O estudo aponta um crescimento de $157 \%$ no total de presos desde 2000, quando o País contabilizava 232 mil encarcerados. Se mantido esse ritmo, em 2022 computaremos 1 milhão de detentos.

Contudo, importante anotar que a política de encarceramento em massa adotado no âmbito da política neoliberal a partir do início da década de 90 no Brasil e que propiciou esse aumento desenfreado da população carcerária, não foi acompanhado da diminuição dos crimes considerados violentos nem tampouco da diminuição da sensação de insegurança por parte da população brasileira, "o que em tese poderia justificar o enorme custo social e financeiro do encarceramento", mas, "pelo contrário, o cárcere tem reforçado mecanismos de reprodução de um ciclo vicioso de violência que, como padrão, envolve a vulnerabilidade, o crime, a prisão e a reincidência e, por vezes, serve de combustível para facções criminosas", pontuam Renato Aragão, Diretor-Geral do Departamento Penitenciário Nacional e Eugênio Aragão, então Ministro da Justiça à época da divulgação dos resultados do Levantamento Nacional de Informações Penitenciárias, de dezembro de 2014.

O que há efetivamente no Brasil é a coexistência de um Estado de Direito instituído - que governa para os incluídos economicamente - e de um Estado de exceção,

22 Segundo dados extraídos do INFOPEN (Relatório de Informações Penitenciárias), disponível em <http:// www.justica.gov.br/seus-direitos/politica-penal/documentos/infopen_dez14.pdf>, acesso realizado em 07/04/2019.

23 Segundo dados extraídos do INFOPEN (Relatório de Informações Penitenciárias), disponível em <http:// www.justica.gov.br/noticias/ha-726-712-pessoas-presas-no-brasil/relatorio_2016_junho.pdf>, acesso realizado em 11/04/2019. 
ao qual estão submetidos os territórios ocupados pela pobreza. Os dados divulgados no relatório sobre a natureza dos crimes que mais levam ao encarceramento revelam que se prende mais os autores de crimes ligados às drogas e contra a propriedade do que os que cometem o crime do homicídio. Essa aparente contradição entre a impunidade no campo dos homicídios e o endurecimento da punição aos crimes relacionados às drogas e crimes contra a propriedade, como roubos e furtos, corresponde, na realidade, ao interesse da elite incluída.

As vítimas dos casos sem conclusão - porque sem empenho efetivo de apuração por parte do poder público - são os pobres, pretos, moradores da periferia, muitas vezes assassinados pelas próprias forças de repressão do Estado.

Temos uma estrutura judicial estabelecida não para realizar justiça de forma universal e democrática, mas sim para investigar os crimes que interessam aos incluídos, àqueles que estão, de fato, sob a proteção do Estado democrático de direito. Como aponta Rafael Valim:“Em síntese, o mercado define os inimigos e o Estado os combate."24

Uma vez mais, lançamos mão das lições de Rubens Casara para compartilhar com o leitor a convergência de ideias entre os autores que estudam com profundidade o fenômeno do Estado de exceção no Brasil, sobretudo no que tange à intrínseca relação do direito penal como instrumento a serviço do poder político/econômico, numa lógica neoliberalista, que escolhe o sujeito do punitivismo estatal:

Da mesma forma, nem todos que praticam condutas consideradas criminosas vão ser processados ou punidos, isso porque, após a criminalização primária (a escolha 'do que punir'), existe a criminalização secundária, que é a escolha, muitas vezes aleatória ou arbitrária, daquelas pessoas que serão investigadas pela polícia, denunciadas pelo órgão acusador (no Brasil, o Ministério Público) e condenadas pelo Poder Judiciário. Na criminalização secundária, as mesmas questões ideológicas, de classe, de gênero, e também racionalidade neoliberal, atuam, o que gera o fenômeno das 'cifras ocultas' - a diferença entre o número de crimes ocorridos, muitos dos quais nunca chegam ao conhecimento das autoridades encarregadas da persecução penal, e aqueles efetivamente investigados, processados e punidos -, razão pela qual o ideal de igualdade perante a lei, que o direito liberal trata como princípio, não passa de um mito na pós-democracia."25

O que mais causa espanto é a banalidade com que a questão é tratada. A ditadura, que foi um marco autoritário em nosso país, um regime típico de exceção, vitimou entre mortos e desaparecidos 434 pessoas, segundo dados da Comissão Nacional da

24 VALIM, Rafael. Estado de exceção: a forma jurídica do neoliberalismo. São Paulo: Editora Contracorrente, 2017, p. 36.

25 CASARA, Rubens R. R. Estado pós-democrático: neo-obscurantismo e gestão dos indesejáveis. Rio de Janeiro: Civilização Brasileira, 2017, P. 98-99. 
Verdade. ${ }^{26}$ As polícias militares estaduais matam 3,5 mil pessoas por ano. Morre mais gente no País por ano do que morreram americanos em uma década da Guerra do Golfo.

Evidentemente que não se pode minimizar o que ocorreu durante a ditadura, um período amargo da nossa história. No entanto, quando se afirma que hoje há um grau muito maior de liberdades e garantias individuais do que naquele período, essa afirmação é bastante relativa, já que esses direitos não foram universalizados. As classes incluídas certamente usufruem dessa liberdade, mas os mais pobres continuam tendo seus direitos básicos sistematicamente subtraídos pelo Estado.

A principal mudança entre o momento atual e a ditadura não foi a garantia de liberdade e o acesso ao direito, mas a escolha do inimigo. Enquanto na ditadura o inimigo - elemento chave para a conformação do Estado de exceção - era o militante comunista, que poderia estar inserido em qualquer classe social, hoje, o inimigo está socialmente localizado: é o pobre.

O instituto da prisão provisória é outro mecanismo que vem sendo largamente utilizado como instrumento de controle social. Segundo o já citado relatório do Infopen, em 2016, quatro em cada dez presos eram provisórios, ou seja, estavam detidos sem terem recebido uma sentença de primeiro grau. O documento do Centro de Estudos de Segurança e Cidadania relata ainda que $72 \%$ dos presos por tráfico no Rio, em 2013, ficaram detidos durante o processo e que, após o julgamento, menos da metade deles, apenas $45 \%$, foram condenados.

Somando-se aos presos provisórios aqueles detentos cujos processos não foram concluídos, chega-se a quase dois terços da população carcerária. Ao contrário do que se pensa, entre $37 \%$ e $50 \%$ dos presos provisórios ou serão inocentados ou receberão penas de reclusão inferiores ao tempo que ficaram privados de liberdade. Isso significa que cerca de $20 \%$ dos presos estão presos injustamente. Diante desses dados, podemos afirmar que não há direito de defesa e presunção de inocência verdadeiramente garantidos a todos os cidadãos.

Discutir penas e sanções alternativas para aqueles que não praticaram crime grave e violento e desbanalizar o uso da prisão provisória - que deve ser usada somente dentro dos parâmetros determinados pela Constituição - são medidas essenciais para que as injustiças, as carnificinas e toda a desumanidade associada à realidade das prisões brasileiras não se perpetue.

É preciso desmistificar a punição. Não aprisionar não significa não punir, porém há mecanismos muito mais eficientes, baratos e adequados para responsabilizar

26 O Relatório Final da Comissão Nacional da Verdade sobre o reconhecimento de mortos e desaparecidos na Ditadura está disponível em: <http://www.cnv.gov.br/images/pdf/relatorio/volume_3_digital.pdf>, acesso realizado em 15/04/2019. 
aquele que comete um delito não violento. Como já afirmamos o aprisionamento em massa não foi acompanhado da redução da violência.

A política de encarceramento, definitivamente, não pode ser considerada produto do Estado democrático, inclusive porque contradiz a ideia de um Estado de direito universal. É um erro no plano político, no plano moral e no plano orçamentário-administrativo.

Superlotar as prisões de jovens pobres, que não representam perigo real para a sociedade, não só não é efetivo para a redução da criminalidade como fatalmente produzirá ainda mais conflitos, mais injustiça e mais violência.

No Brasil, por sua característica como um país de modernidade periférica (processo constitutivo da centralização e modernidade europeia), sempre houve o problema da colonialidade do poder como obstáculo à concretização universal dos direitos previstos constitucionalmente, conforme nos alerta Luis Eduardo Gomes do Nascimento $^{27}$. O que temos, em verdade, é um modelo de uma construção de nação parcial, a exemplo da Constituição Federal de 1934, que apesar de festejada pela comunidade jurídica como a primeira Constituição brasileira a garantir verdadeiramente um conjunto de direitos sociais mínimos e estabelecer uma democracia moderna com a instituição do voto secreto e constitucionalização do voto feminino ${ }^{28}$, não havia ainda, contudo, permissão para o voto do analfabeto.

Apesar dos avanços sociais festejados à época, é bem verdade que com a vedação ao voto dos analfabetos na Constituição de 1934 (artigo 108, "a"), grande parte da população negra e pobre permaneceu excluída do exercício da cidadania, uma marca do aspecto da colonialidade que desmistifica o discurso universalizante dos direitos.

Some-se a isso o projeto elaborado pela Comissão Brasileira de Eugenia que trouxe o artigo 138, "b", à Constituição Federal de 1934, determinando o estímulo à educação eugênica no país, sob a responsabilidade da União, dos Estados e Municípios, nos termos da respectiva lei, com o intuito confessado e deliberado de que os jovens não contraíssem matrimônio com raças e classes sociais diferentes, cujo objetivo era o de promover o progresso da nação e a formação de uma elite nacional. Nos debates da Assembleia Nacional Constituinte de 1934 fica claro que a proteção social deveria ser garantida pelo Estado, mas que para o negro e deficiente essa proteção em nada adiantaria.

\footnotetext{
27 Disponível em: <http://justificando.cartacapital.com.br/2017/06/29/direito-modernidade-periferica-e-colonialidade-do-poder/>, acessado em 20/04/2019.

28 Apesar do voto secreto e o direito ao voto feminino ter sido reconhecido com a entrada em vigor do Código Eleitoral Provisório, Decreto n 21.076, de 24 de fevereiro de 1932, durante o governo de Getúlio Vargas, fruto de uma conquista do movimento sufragista, após intensa luta e reinvindicações no cenário nacional e internacional, somente em 1934 esse direito se constitucionaliza. Contudo, o exercício do direito ao voto das mulheres ainda era facultativo para a maioria delas, salvo para aquelas que exerciam função pública remunerada.
} 
Portanto, podemos notar a partir dos exemplos acima citados, os símbolos que marcam a cultura e historicidade da nação brasileira, uma nação que cria mecanismos avançados de direitos, mas sem criar uma política verdadeiramente includente para a população como um todo.

Torna-se evidente historicamente que sempre houve no Brasil um sistema de percussão contra negros e pobres que vivem marginalizados, mas, incontestavelmente, nunca de forma tão intensa como com a chegada do neoliberalismo, que marca o aumento acelerado da violência, do aprisionamento em massa e do fortalecimento dos instrumentos de persecução penal e punitivismo estatal:

Desnecessário dizer que, neste contexto, o Direito Penal e o Direito Processual Penal sofrem um completo desvirtuamento, perdendo sua vocação garantista em prol da mera legitimação das pretensões autoritárias do Estado. A persecução penal se torna um jogo de cartas marcadas, com um absoluto desprezo ao direito de defesa. ${ }^{29}$

Com a política neoliberal e a globalização, ocorre um encontro da realidade global com a realidade local, o "caldo" político, social e cultural brasileiro favorece a chegada desse modelo de Estado e de uma nova forma de capitalismo, transformando-se em eminentemente financeiro, pós-industrial.

A colonialidade do poder marca-se pela imposição da ideia de raça como mecanismo de dominação. Achile Mbembe com argúcia mostra como a ideologia de raça funciona como mecanismo perverso de poder:

Nesse contexto, os novos processos de racialização visam a marcar grupos de populações, a fixar o mais precisamente possível os limites no seio das quais elas podem circular, a determinar o mais exatamente possível a colocação que podem ocupar, enfim, assegurar as circulações no sentido que permite afastar as ameaças e assegurar a segurança geral. Trata-se de selecionar esses grupos de populações, de marcá-los a sua vez como espécies, séries e como casos, no seio de um cálculo generalizado de risco, de acaso e de probabilidades, de maneira a poder prevenir os perigos inerentes a sua circulação $e$, se possível, a neutralizar seu avanço tanto pelo encarceramento quanto pela deportação. A raça, desse ponto de vista, funciona ao mesmo tempo como ideologia, dispositivo de segurança e tecnologia do governo das multiplicidades. Ela é o meio mais eficaz de abolir os direitos no ato mesmo pelo qual se pretende erigir a lei ${ }^{30}$.

O esvaziamento dos direitos sociais e os retrocessos civilizatórios que experimentamos na agenda política atual e em curso, a exemplo das reformas trabalhistas e

29 VALIM, Rafael. Estado de exceção: a forma jurídica do neoliberalismo. São Paulo: Editora Contracorrente, 2017, p. 36.

30 MBEMBE, A. Prefácio. FANON, Franz. Oeuvres. Paris: La découverte, 2011, p. 20. 
previdenciária e a recente aprovação da PEC dos gastos públicos que reduz exponencialmente os custos com direitos sociais, como saúde e educação, terão o potencial de impelir um grande contingente da nossa população àquilo que o filósofo e historiador camaronês Achille Mbembe chama de "devir-negro31" dos nossos tempos, ou seja, a uma condição de subalternidade e vulnerabilidade semelhante à do negro escravizado pela civilização ocidental entre os séculos XV e XVIII.

Ao apontar o neoliberalismo como terceiro momento que marca a biografia do Negro e da raça com o seu sentido negativo ou na sua dimensão fantasmagórica como enuncia, em "Crítica da razão negra", Mbembe adverte-nos para uma tendência à universalização da condição negra aos que ele denomina de humanidade subalterna:

Desde logo, os riscos sistemáticos aos quais os escravos negros foram expostos durante o primeiro capitalismo constituem agora, se não a norma, pelo menos o quinhão de todas as humanidades subalternas. Depois, a tendencial universalização da condição negra é simultânea com a instauração de práticas imperiais inéditas que devem tanto às lógicas esclavagistas de captura e de predação como às lógicas coloniais de ocupação e exploração, ou seja, às guerras civis ou razzias de épocas anteriores. ${ }^{32}$

Em recente artigo publicado na internet sob o título: Bajo el signo del poder de policía ${ }^{33}$, Raúl Zaffaroni afirma que estamos vivendo sob o signo de um poder totalitário, colonialista e delinquencial que não instala propriamente uma ditadura mas que provoca a degradação do Estado de direito. Em suas palavras:

Este poder totalitario colonialista y delincuencial no instala una "dictadura", sino que deteriora y degrada al Estado de Derecho (que somete a todos por igual a la ley), que nunca en el mundo real llega a ser como su modelo ideal. El Estado de Derecho es una cápsula que contiene a su contrario, que es el Estado de policía (que somete a todos a la voluntad arbitraria de los que mandan), que tampoco nunca es como su modelo ideal.

\section{(...)}

\footnotetext{
31 "Pela primeira vez na história humana, o nome Negro deixa de remeter unicamente para a condição atribuída aos genes de origem africana durante o primeiro capitalismo (predações de toda a espécie, desapossamento de autodeterminação e, sobretudo, das duas matrizes do possível, que são o futuro e o tempo). A este novo caráter descartável e solúvel, à sua institucionalização enquanto padrão de vida e à sua generalização ao mundo inteiro, chamamos o devir-negro do mundo... In: MBEMBE, Achille. Crítica da razão negra. Trad. Marta Lança. Lisboa: Antígona, 2014, p. 18.

32 MBEMBE, Achille. Crítica da razão negra. Trad. Marta Lança. Lisboa: Antígona, 2014, p. 16.

33 Disponível em: http://www.nuestrasvoces.com.ar/a-vos-te-creo/signo-del-poder-policia/, acessado em $15 / 04 / 2019$.
} 
Estamos viviendo en un Estado de Derecho deteriorado, degradado, debilitado, con deterioro de la política y de las instituciones democráticas, con pérdida de seguridad jurídica, carente de una justicia imparcial, con un Ejecutivo unipersonal que manipula al Legislativo y al Judicial, con un monopolio mediático que crea realidad a gusto, es decir, un Estado que pierde soberanía y con ella independencia, como lo quiere esta etapa del colonialismo, inherente a la condición periférica del totalitarismo corporativo.

De alguma forma, vários autores nacionais e estrangeiros perceberam esse fenômeno que pesquisamos desde 2007 e que temos denominado de medidas de exceção adotadas como técnicas de governo no interior das sociedades democráticas. Norberto Bobbio chama de "novos despotismos" ${ }^{34}$, que apesar de tratar da Itália na sua fase Berlusconista, é uma forma que se universaliza; Luigi Ferrajoli descreve o processo de esvaziamento da constituição e da crise democrática italiana como "poder desconstituinte" ${ }^{\prime 35}$, conceito que também pode ser partilhado entre os países de constituições rígidas adotadas no pós-segunda guerra; Ronald Dworkin aponta a perda do "common ground ${ }^{36 "}$ da sociedade; Boaventura de Souza Santos fala de "democracia de baixa intensidade" 37 ; Claus Roxin chama de "populismo penal"; Rubens Casara de "Estado Pós-Democrático"38 e, finalmente, "Estado de exceção"39 em Giorgio Agambem, conceito que adotamos e estudamos nesse livro em capítulo anterior, e que também é utilizado por diversos autores, tais como: Carpentier, Codaccioni, Goupy, Rafael Valim, Georges Abboud, Lenio Luiz Streck, Fernando Hideo I. Lacerda, Gilberto Bercovici, entre tantos outros que tratam do tema.

Contudo, a maioria dos autores referidos acima trata do tema a partir da lógica do primeiro mundo, marcadamente a Europa, onde se tem, grosso modo, a edição de atos do Legislativo - por meio de normas gerais e abstratas - que fortalecem o Executivo, a exemplo das leis anti-terrorismos. Nos países de capitalismo tardio e desiguais da América Latina, as medidas de exceção são direcionadas ao inimigo interno, que pode ser tanto o bandido (parcela pobre, majoritariamente negra, e marginalizada da sociedade), como o corrupto. Nesse último caso, por meio do sistema de Justiça que atua a serviço dos interesses do mercado e opera para criminalizar lideranças de esquerda ou nacionalistas.

\footnotetext{
34 BOBBIO, Norberto. Contra os novos despotismos: escritos sobre o berlusconismo. São Paulo: Editora Unesp; Instituto Norberto Bobbio, 2016.

35 FERRAJOLI, Luigi. Poderes Selvagens: a crise da democracia italiana. São Paulo: Saraiva, 2014.

36 DWORKIN, Ronald M. Is democracy possible here? : Principles for a new political debate. New Jersey: Princeton University Press, 2008.

37 SANTOS, Boaventura de Sousa. A difícil democracia. São Paulo: Boitempo, 2016.

38 CASARA, Rubens R. R. Estado pós-democrático: neo-obscurantismo e gestão dos indesejáveis. Rio de Janeiro: Civilização Brasileira, 2017.

39 AGAMBEM, Giorgio. Estado de exceção. Tradução de Iraci D. Poleti. 2. ed. São Paulo: Boitempo, 2011.
} 
Neste sentido, com relação à parcela da população incluída surgem essas medidas de exceção com finalidade política em duas modalidades: a) impeachment e golpes de Estado; b) processos penais de exceção e persecução de líderes políticos, em geral, de esquerda.

Na América Latina, golpes militares clássicos como os ocorridos no Brasil, na Argentina e no Chile, são um fenômeno do século XX, que ficaram para trás. No século XXI, estabeleceu-se no mundo ocidental um forte consenso democrático, ou seja, consolidou-se um discurso de legitimação da democracia como valor universal.

Entretanto, isso não significa que o autoritarismo deixou de existir no interior dos Estados democráticos. As medidas autoritárias apenas passaram a ser revestidas de uma aparência de legitimidade democrática, sem interdição declarada da ordem jurídica.

Essas medidas representam uma fraude, pois embora tenham uma forma jurídica que procura ter aparência de adequação, descumprem princípios fundamentais do Estado de direito, sendo chamadas pela doutrina moderna de medidas de exceção, tal como descritas por Giorgio Agamben.

Esse tipo de medida de exceção vem sendo aplicada na América Latina, nos últimos anos, principalmente contra governos de esquerda, contando com a participação ativa do Poder Judiciário.

E, diferentemente da Europa e dos EUA, onde a exceção se produz por meio da lei ou de institutos semelhantes - como o Patriotic Act e leis antiterroristas europeias, altamente suspensivas de direitos de determinados grupos considerados inimigos do Estado -, na América Latina as medidas de exceção têm sido produzidas, no campo político, pelo judiciário ou pelo legislativo juntamente com o judiciário, e, no campo dos direitos fundamentais individuais, pela jurisdição.

Em Honduras e no Paraguai, em 2009 e 2012, respectivamente, interromperam-se mandatos presidenciais legitimamente constituídos, sem devido processo legal, contrariamente às normas constitucionais desses países, com o beneplácito ou atuação direta do judiciário, como veremos no último capítulo.

É bem verdade também que os governos de esquerda do continente valem-se de medidas de exceção travestidas de legalidade, a fim de penalizar seus oponentes. $\mathrm{Na}$ Venezuela, por exemplo, o judiciário tem sido utilizado para punir lideranças de oposição pela suposta prática de crimes comuns, quando na verdade são punidos pelo exercício de atividade política. Há, portanto, suspensão de direitos, sob a aparência de ações legítimas e democráticas típicas de medidas de exceção.

O mesmo se conclui quanto ao impeachment da presidente Dilma. Sem qualquer fundamentação jurídica, tivemos a concretização de uma medida de exceção com a finalidade política de interromper ilícita, inconstitucional e agressivamente um 
mandato legítimo, suprimindo a soberania popular e o direito político de mais de 54 milhões de pessoas, esvaziando, assim, a democracia.

Essa suspensão grave de direitos vem sendo justificada pelos oponentes da continuidade do governo com o argumento falacioso e cínico de que se busca combater o inimigo da vez - o corrupto, também personificado no "petralha" e no militante de esquerda.

O fato de se tratar de uma medida de exceção não retira, evidentemente, a legitimidade de o ativista político utilizar a expressão "golpe" para se manifestar e traduzir a ideia de ameaça de uma grave agressão à democracia e à Constituição. Sob o ponto de vista técnico, de teoria do Estado, porém, não há um golpe, mas sim uma medida de exceção.

O Judiciário funcionou nesse processo como legitimador da exceção perpetrada, pois embora o Supremo Tribunal Federal tenha determinado as regras do processo de impeachment, não se pronunciou até hoje sobre as medidas que contestam o processo.

Ao lado dos mecanismos de interrupção dos ciclos democráticos por meio de impeachments inconstitucionais e golpes perpetrados contra governos principalmente de esquerda, vem ocorrendo também na contemporaneidade a criminalização dos agentes políticos seletivamente selecionados por não representarem os interesses e privilégios do mercado, por meio de um verdadeiro processo penal de exceção, expressão cunhada com acerto por Fernando Hideo, em tese de doutoramento defendida na PUC/SP em 2018, mas que, em linhas gerais, em artigo recentemente publicado, traz a seguinte ideia:

O processo penal de exceção é um antiprocesso. É a forma jurídica da perseguição política e econômica na era da pós-verdade. É a violação dos direitos e garantias fundamentais de uma parcela da população (e de seus representantes simbólicos) com verniz hipócrita de licitude. É fruto da manipulação do sistema de justiça criminal (Polícia, Ministério Público, Poder Judiciário e Mídia) para atender aos interesses do mercado contra seus verdadeiros inimigos: o pobre, marginalizado e oprimido. ${ }^{40}$

A doutrina do Direito Penal do Inimigo criada na década de 1980 pelo jurista alemão Günther Jakobs propõe uma distinção entre o Direito Penal do Cidadão e um Direito Penal do Inimigo. O primeiro formado pela aplicação das normas penais vigentes, com respeito às garantias individuais dos cidadãos e exercida nos estritos limites do poder punitivo estatal impostos no âmbito da legalidade e o segundo, um direito

40 LACERDA, Fernando Hideo I. A caçada de Lula pelo processo penal de exceção na era da pós-verdade. Artigo publicado na obra coletiva: Comentários a uma sentença anunciada: o processo Lula. Organizadores: Carol Prosner et al. (orgs). Bauru: Canal 6, 2017, p. 164. 
penal especial, voltado aos inimigos, em que há a aplicação de atos lícitos ou ilícitos aos indivíduos que põe em risco a segurança nacional. Já não há mais qualquer proteção a direitos e garantias penais e processuais penais mínimos, como bem observa a pesquisadora Charlotth Back:

Em nome da defesa da sociedade, as garantias penais mínimas consagradas pelas constituições e pelos instrumentos internacionais de proteção dos Direitos Humanos, como a presunção de inocência, a vedação da condenação sem provas, o princípio da legalidade, a neutralidade do julgador, a proibição da tortura, bem como o impedimento de obtenção de provas por meio ilícitos, não se aplicam aos proclamados 'inimigos da sociedade. $^{\prime 11}$

Enquanto nos EUA e nos países da Europa continental podemos reconhecer de forma explícita uma jurisprudência do direito penal de exceção e medidas de exceção no direito penal por meio da criação de leis especiais - ou Direito Penal do Inimigo para ficarmos na expressão cunhada por Jakobs - em razão de um direito especial que é criado para questões de segurança nacional, identificadas com as ameaças terroristas (o inimigo é o estrangeiro e não se identifica com os indivíduos daqueles países), aqui no Brasil é o próprio direito comum que é utilizado para combater o inimigo (o pobre, o bandido, o corrupto), não pela aplicação de um direito penal ou processual diferenciado para combatê-lo, senão pela utilização de interpretações das normas penais comuns como mecanismos para se instaurar as medidas de exceção contra a própria população que se quer excluir, sob um pretenso legítimo discurso de legalidade democrática.

Nesse sentido, o sistema de justiça criminal, composto por vários agentes estatais (Poder Judiciário, Ministério Público, Delegados, Polícia, etc.), com o apoio fundamental da mídia ${ }^{42}$, torna-se o autor soberano das medidas de exceção, tendo como base social de apoio a "ralé" 43 que busca a ordem e, sobretudo, a extinção dos conflitos sociais e políticos.

41 BACK, Charlotth. Direito penal do inimigo político. Artigo publicado na obra coletiva: Comentários a uma sentença anunciada: o processo Lula. Organizadores: Carol Prosner et al. (orgs). Bauru: Canal 6, 2017, p. 106.

42 "Hoje é impossível pensar o funcionamento do Sistema de Justiça Criminal sem analisar o funcionamento dos meios de comunicação de massa, que produzem hipóteses acusatórias, selecionam 'provas', julgam (sem os limites impostos pelas constituições democráticas) e executam pessoas diante de seus leitores, ouvintes e espectadores. Não raro, os julgamentos e execuções midiáticas são mais céleres e festejados do que aqueles realizados pelo Poder Judiciário. Não raro, os julgamentos midiáticos influenciam os julgamentos do Poder Judiciário, isso porque muitos juízes também querem ser festejados pelos meios de comunicação de massas." In: CASARA, Rubens R. R. Estado pós-democrático: neo-obscurantismo e gestão dos indesejáveis. Rio de Janeiro: Civilização Brasileira, 2017, p. 99-100.

43 "A ralé é fundamentalmente um grupo no qual são representados resíduos de todas as classes. É isso que torna tão fácil confundir a ralé com o povo, o qual também compreende todas as camadas sociais. Enquanto o povo, em todas as grandes revoluções, luta por um sistema realmente representativo, a ralé brada sempre pelo 'homem forte', pelo 'grande líder'. Porque a ralé odeia a sociedade da qual é excluída, e odeia o Parlamento 
Na América Latina vem ocorrendo a substituição da farda pela toga. Na década de 1960 os militares eram os soberanos purificadores, considerados moralmente neutros, livres das impurezas da política e detentores da força física necessária para impor a ordem, papel hoje desempenhado na crença e imaginário dessa "ralé" pelas carreiras públicas que compõem o sistema de justiça.

O conceito de ralé é trazido por Hannah Arendt em "As origens do totalitarismo" ao buscar entender como o nazismo conseguiu se instalar na Alemanha. Ela cria o conceito de ralé como substituto de povo. Um povo não é um mero aglomerado de pessoas em um regime democrático, mas sim um conjunto de pessoas que partilha uma certa visão de sociedade e certos valores.

Em um regime democrático, a sociedade é um ente dividido, frágil e conflitivo, que resolve seus conflitos por mecanismos pacíficos, por meio da Política e do Direito. Já a ralé se reúne em torno de um líder ou de um estamento carismático e tem uma noção de dever ser, uma noção corretiva da sociedade. A sociedade deve ser pura e unida, não deve ter conflitos, mas sim ordem.

A ralé tem uma visão de mundo autoritária, incompatível com a democracia. É uma base social essencial para existir a exceção. Uma característica dos Estados de exceção no século XX é que eles sempre tiveram uma forte base social, como foram os casos do nazismo, do fascismo e de várias ditaduras latino-americanas.

No Brasil, essa ralé quer o Judiciário não como produtor de justiça ou aplicador de direitos, mas sim como combatente do crime e fonte da ordem. Essa vontade cria o ambiente para o surgimento de juízes que agem como promotores e para a violação de direitos fundamentais.

Na contemporaneidade, a exceção vem sendo produzida em consequência de uma visão típica de uma direita conservadora e autoritária, que acredita na necessidade, com fundamento, em geral, na questão da segurança, de o Estado exercer maior poder e controle sobre as comunidades.

Isso implica trazer o regime jurídico próprio da guerra para o plano interno, tomando parcela da sociedade como inimiga e retirando daqueles que fazem parte desse grupo a condição humana que lhes confere proteção política e jurídica. Assim, é possível ao Estado sujeitá-los a um controle biojurídico e biopolítico, sem reconhecer-lhes qualquer direito.

Embora muitas vezes a exceção se empregue a partir de mecanismos jurídicos, sua motivação é sempre política e sua adoção, sempre justificada pela emergência no aspecto temporal e insegurança no campo social e axiológico. O conceito de exceção

onde não é representada." In: ARENDT, Hannah. Origens do totalitarismo. Trad. Roberto Raposo. São Paulo: Companhia das Letras, 1989, p. 129. 
pressupõe ainda que os direitos próprios da democracia liberal são adequados para reger a vida cotidiana.

É na excepcionalidade, ou seja, numa situação em que o Estado se vê ameaçado pelo inimigo, que esses direitos podem ser suspensos - semelhante ao que ocorre em relação ao estado de sítio no Brasil e o estado de guerra na Inglaterra.

Por haver a suspensão de direitos e do Direito em si, essa relação autoritária é, conforme observado por Juan Donoso Cortés, Carl Schmitt, Santi Romano, Baladore-Pallieri, Giorgio Agamben, Carpentier e uma série de outros pensadores, própria do campo da anomia.

A ideia de exceção, tanto no plano no Direito quanto no âmbito da Teoria do Estado e da Filosofia política, sempre se circunscreveu no campo da anomia, ou seja, da ausência de norma. A relação autoritária do Estado para com os indivíduos se dá por meio da suspensão de direitos humanos e fundamentais e pelo estabelecimento de uma espécie de soberania bruta, em que a vontade do soberano se impõe ao cidadão - algo semelhante à estrutura do império absolutista.

No entanto, há um outro fenômeno pouco percebido na contemporaneidade que é a produção de exceção em decorrência não da ausência, mas do excesso de normas.

Segundo estudo do Instituto Brasileiro de Planejamento e Tributação (IBPT) ${ }^{44}$, desde a promulgação da Constituição de 1988 até setembro de 2016, já haviam sido editadas 5,4 milhões de normas para regular a vida do cidadão brasileiro, o que corresponde a uma média de 800 normas por dia. Essa alta produção normativa refere-se não só ao direito tributário, mas a todas as áreas do Direito.

Além da quantidade, a complexidade da legislação brasileira é outro imenso empecilho à garantia de segurança jurídica, como observa Rafael Valim em seu trabaIho sobre segurança jurídica, no âmbito do direito administrativo ${ }^{45}$.

Pelo emprego cada vez mais rotineiro da utilização de conceitos indeterminados na elaboração das normas de direito sancionatório, em especial do penal, conceitos muito amplos e que abrangem potencialmente um grande número de situações, dificulta ao cidadão prever como o Estado vai reagir frente à sua conduta. O nullum crimen sine lege - não há crime sem lei anterior que o preveja -, um princípio de garantia da liberdade, que assegura a previsibilidade da conduta estatal, está sendo extremamente fragilizado.

Tais condições facultam que quase todas as condutas humanas que fogem do banal possam, por alguma interpretação jurídica e pelo que, em texto coletivo escrito

\footnotetext{
44 Disponível em: <https://ibpt.com.br/noticia/2603/Brasil-edita-cerca-de-800-normas-por-dia-somando-5-4-milhoes-desde-a-Constituicao-de-1988>, acesso realizado em 20/04/2019.

45 VALIM, Rafael. $\mathbf{O}$ princípio da segurança jurídica no direito administrativo brasileiro. São Paulo: Malheiros, 2010.
} 
com Luis Eduardo Gomes do Nascimento ${ }^{46}$, temos chamado de apropriação privada da linguagem pelo intérprete, se tornar passíveis de sanção pelo Estado. E esse imbróglio normativo acaba por delegar a quem executa a lei - o delegado, o promotor, o juiz, o fiscal, o agente público em geral - o poder arbitrário, imperial, absolutista, de selecionar quem é atingido por essa norma e quem não é: isso é a essência da exceção.

Em suma, o excesso normativo equivale à inexistência de norma. A hipernomia tem o mesmo sentido da anomia. O pressuposto que antecede a produção de sistemas sancionatórios é a definição do que é lícito e do que é ilícito. Quando tudo se torna ilícito, deixa de existir por não cumprir seu pressuposto sintático e ôntico primário.

Assim, a hipernomia, incluindo a produção de normas de conceito impreciso, fenômeno que ocorre hoje no mundo todo e especialmente no Brasil, submete os cidadãos a um poder arbitrário e de exceção, pois não há nenhum controle de validade sobre o espectro normativo onde existe a norma.

Embora, em especial nas normas sancionatórias que se vertem por conceitos indeterminados, seja possível alegar inconstitucionalidade da norma isolada, o fenômeno da inconstitucionalidade por hipernomia sancionatória ocorre em relação ao subsistema sancionatório e não na norma isoladamente considerada.

O fato de a sanção estar lastreada em lei não dá ao cidadão a garantia de que a aplicação normativa do sistema normativo sancionatório, por parte dos agentes incumbidos de sua execução, esteja ocorrendo segundo a lógica própria do direito e segundo os valores mais elementares do Estado democrático de direito.

O âmbito de abrangência da legislação sancionatória é tão extenso que retira do poder legislativo a prerrogativa de discriminar quem é potencialmente culpado perante o sistema, incumbindo tal decisão ao arbítrio seletivo do aplicador do sistema normativo.

Esse novo fenômeno do Direito e da Teoria do Estado requer atenção e está intimamente relacionado, no plano político a esse momento de forte distanciamento entre capitalismo neoliberal e democracia liberal.

A legalidade sancionatória está paulatinamente perdendo o seu caráter de proteção e convertendo-se em mecanismo de exceção. Na forma hipernômica, as relações entre o Estado e os indivíduos se dão sob a aparente vigência de um Estado de direito, quando, na realidade, vigora um Estado autoritário, em tensão constante com os valores democráticos.

Pela produção hipernômica no campo penal e pela indeterminação intencional da norma, a sociedade como um todo se torna um potencial criminoso. Trata-se de um mecanismo de medida exceção muito sutil porque usa da forma do Estado de direito

46 Disponível em: <http://justificando.cartacapital.com.br/2017/05/31/wittgenstein-e-hermeneutica-juridica-analogica/>, acesso realizado em 20/04/2019. 
que é a lei, para expurgar essa separação. Sob o ponto de vista da decisão legislativa tudo é ilícito e cabe ao agente aplicador da lei o poder anômico (quer dizer uma hipernomia que gera anomia) de poder selecionar quem será aprisionado ou não.

O momento que atravessamos significa a culminação daquilo que o jurista italiano Luigi Ferrajoli identificou em seu país como um forte processo de desconstitucionalização ou poder desconstituinte, caracterizado pelo esvaziamento de sentido da Constituição vigente, transformando-a em uma mera casca, um disfarce, reduzindo a democracia à prática do voto universal.

Uma democracia pode ser derrubada sem golpes de Estado formais se os princípios dela forem de fato violados ou contestados, sem que suas violações suscitem rebeliões ou ao menos dissenso. Recordemos o último artigo da Constituição francesa do ano III: 'o povo francês confia a presente Constituição à lealdade' dos poderes públicos e à 'vigilância dos pais de família, às esposas e às mães, ao afeto dos jovens cidadãos, à coragem de todos os franceses.' É com base nestas duas garantias, de caráter político e social - a garantia política da 'lealdade' dos poderes públicos e a garantia política da 'vigilância' dos cidadãos -, que repousa a efetividade das garantias jurídicas e com estas, do Estado de direito e da democracia. ${ }^{47}$

Esse processo desconstituinte nada mais é do que um fenômeno de subversão da regra democrática que, desde o período pós Segunda Guerra Mundial, deixou de ser vista apenas como o regime pelo qual se obtém decisões majoritárias - conforme a definição de Norberto Bobbio -, para se tornar um padrão em que as decisões majoritárias ficam submetidas a uma Constituição e ao sistema de direitos fundamentais.

Não há propriamente o afastamento do regime democrático que sobrevive apenas discursivamente e formalmente, mas, de fato, na vida vivida, seus pressupostos mais elementares são constantemente violado, a serviço principalmente da manutenção dos privilégios do poder econômico. É o que nos apresenta Rubens Casara, conforme trecho que destacamos:

Na pós-democracia, o significante 'democracia' não desaparece, mas perde seu conteúdo. A democracia persiste como uma farsa, uma desculpa que justifica o arbítrio. Em nome da 'democracia', rompe-se com os princípios democráticos. (...) Trata-se de uma 'democracia' em que desaparece a premissa de um governo do povo por ele mesmo e que também desconsidera direitos democráticos, como o da livre determinação dos povos. $^{48}$

47 FERRAJOLI, Luigi. Poderes Selvagens: a crise da democracia italiana. São Paulo: Saraiva, 2014, p. 15.

48 CASARA, Rubens R. R. Estado pós-democrático: neo-obscurantismo e gestão dos indesejáveis. Rio de Janeiro: Civilização Brasileira, 2017, P. 31. 
As constituições rígidas estabelecidas na Europa continental a partir de então, ao trazerem uma pauta de direitos positivos e negativos, como aponta Ferrajoli, tornaram necessárias alterações nas teorias jurídica e política e também no conceito de democracia liberal.

A decisão política já não pode mais ser vista como independente da decisão majoritária porque seu conteúdo passa a ser condicionado pela Constituição. Já não é possível ofender certos direitos e há a obrigação de assegurar tantos outros - as liberdades públicas e os direitos sociais.

Esta concepção de democracia construída pelo novo constitucionalismo do pós-guerra coincide com o ápice histórico do chamado Estado social. Como se sabe, a crise do Estado de bem-estar social chegou ao seu estágio terminal no final da década de 1980, com o surgimento de um novo paradigma de capitalismo - o mal alcunhado, já que de liberal não tem quase nada, neoliberalismo.

Esse modelo, que visava substituir o projeto econômico do Estado social por um projeto econômico meramente de mercado, acabou se transformando em um fenômeno muito mais complexo, tornando-se não apenas um modelo que busca ampliar o poder de mercado, mas também globalizar o sentido da economia, necessitando para isso alterar as formas políticas e as formas jurídicas.

Nesse contexto, a alteração das configurações políticas se dá pela produção de novas formas estatais, sem, entretanto, levar em conta aquilo que Giorgio Agamben chama de "formas de vida". A criação da União Europeia, como apontado por esse autor, é exemplar da criação de uma nova forma política que desconsidera as formas de vida - a cultura, as tradições e até mesmo as políticas e as jurisprudências - dos Estados e povos que o integram.

O resultado, prevê Agamben, é uma crise constante que, ou levará à ruptura como já se observa com a saída do Reino Unido do bloco -, ou a um grande crime de lesa humanidade de natureza cultural - a eliminação de um pedaço da história dos povos e de formas plurais de vida. Tais modelos não se solidificam porque, para além das questões políticas e econômicas, há os conflitos de identidade cultural, que geram resistência a essa tentativa de uniformização das formas de vida.

Na esteira dessas novas conformações, o Brasil desponta com características interessantes. Esse modelo que propõe uniformidade global nas formas jurídicas e políticas chega aqui na década de 1990 e, por meio de reformas inconstitucionais que buscavam transformar os serviços públicos em public utilities, altera a estrutura essencial do Estado brasileiro, tal como estabelecido na Constituição de 1988.

O processo que começa com a transferência de serviços antes titularizados pelo Estado para a iniciativa privada vai avançando para outros ambientes, tanto no campo das liberdades públicas quanto no campo dos direitos sociais, gerando uma enorme desigualdade social. A principal característica do Estado criado por esse modelo de capitalismo é o fato de ele demandar mecanismos autoritários para poder se concretizar. 
A fim de conter o caos social, a guerra civil permanente, que emerge desse modelo gerador de desigualdades, suspendem-se os direitos fundamentais de parcela da população e se impõe uma soberania bruta, violenta, a que se costuma chamar de Estado de exceção. A nossa tradição política, cujo autoritarismo sempre se impôs por meio de fraudes, de artimanhas político-jurídicas com aparência democrática, acolheu muito facilmente o paradigma autoritário advindo dessa nova forma de capitalismo.

Como diz Norberto Bobbio, democracia é um procedimento, um processo de disputa, que visa preservar a paz. É por meio da disputa política, da disputa do voto e, depois, de um processo de deliberação entre os legisladores e representantes da sociedade civil, por exemplo, que os conflitos de interesse entre os distintos grupos são resolvidos por decisão majoritária.

Luigi Ferrajoli destaca que após as Constituições do pós-guerra, rígidas, a definição de Bobbio, e de Hans Kelsen, também precisa ser acrescida de dimensões materiais relativas à proteção das liberdades públicas e à efetivação dos direitos sociais, limitando, portanto, o conteúdo da decisão política majoritária.

A democracia não pode, no entanto, ser entendida apenas como um regime político do Estado. Democracia é muito mais do que isso e para que se efetive depende de como se comporta a sociedade. Não se pode manter um Estado democrático com uma sociedade autoritária. Há uma inter-relação evidente entre Estado e sociedade que leva o grau de democracia que de fato existe nessa sociedade a se refletir nas condutas concretas do Estado.

É comum ouvirmos de debatedores de parte a parte que democracia é divergir e que, portanto, conflitar é a atitude verdadeiramente democrática. Há, obviamente, alguma verdade nesse argumento. Não se deve jamais discutir o direito do indivíduo a divergir. A democracia só se sustenta se for garantida a qualquer cidadão a possibilidade de discordar, inclusive quando se opõe às estruturas de poder ou a qualquer decisão estatal, jurisdicional, legislativa ou administrativa.

Por outro lado, é verdade que esse debate não deve funcionar como ato de guerra. Numa sociedade que tem o mínimo de maturidade democrática, o debate, por mais competitivo, deve ter a funcionalidade argumentativa.

Se um diálogo argumentativo e minimamente racional produz divergência aliás, é da natureza do debate gerar divergências -, ao mesmo tempo produz consenso entre seus debatedores, mesmo que não explícito, como pressupostos valorativos gerais. Todo debate racional produz consenso e dissenso. O dissenso acaba por gerar um consenso que, por sua vez, produz novo dissenso e, assim, sucessivamente.

Uma sociedade não consegue ser democrática se, a par das divergências existentes, não atingir um patamar valorativo mínimo em comum. Quando o debate público perde a racionalidade e ganha o território da emoção, passa-se a produzir certas visões de mundo mais pautadas em afeto e menos em lógica e coerência. E só será 
possível superar esse tipo de posição afetiva, normalmente mais autoritária, desarticulando-se esses afetos e criando-se um mínimo de predisposição à convergência e à formação daquilo que Dworkin chama de common ground, ou seja, de padrões mínimos de consenso, o que fortalece a democracia.

\section{CONCLUSÕES}

Na sociedade contemporânea ocidental, a democracia foi concebida por um processo histórico e surgiu como alternativa concreta a partir das revoluções gloriosa, francesa e americana. Foi a partir do século XVIII e, marcadamente nos séculos XIX e XX, que um pacto humanista entre conservadores céticos, liberais e a esquerda democrática se firmou. Por maiores que tenham sido as divergências entre esses segmentos - e foram muitas e substanciais -, como havia uma pauta humanista mínima comum a todos, ao menos no campo dos direitos negativos, ou seja, dos direitos do indivíduo e/ ou das comunidades face ao poder do Estado, e de valores morais mínimos relativos a dignidade humana, formou-se um certo consenso civilizatório.

As consequências desse consenso transcenderam o âmbito do Direito e passaram a gerar uma moralidade própria, ou seja, um conjunto mínimo de valores morais compartilhados por todos. Os mecanismos de sublimação ou de autorrepressão humana, imprescindíveis para se garantir a convivência, se estabeleceram a partir dessa visão humanista comum. É graças à moralidade advinda desse consenso civilizatório mínimo que qualquer indivíduo de bom senso entende, ou deveria entender, que diante da enfermidade ou da morte de um desafeto ou de seu familiar o momento de dor deve ser respeitado. Seria desumano aproveitar-se da fraqueza extrema do adversário para querer fustigá-lo. Essa honorabilidade na disputa e o reconhecimento da condição humana do adversário é algo inerente a esse pacto.

Quando observamos o ódio do discurso, o debate raivoso, o despudor no ataque ao oponente em momentos de vulnerabilidade e a ausência de formação de consensos mínimos, dá-se justamente o "common ground" humanista de civilização. Isso se traduz no comportamento dos indivíduos, que deixam de ter freios de sublimação e passam a expressar o lado mais primitivo das emoções humanas. Isso não só dificulta a vida em comum, num processo que se quer democrático, mas também abre amplo espaço para o surgimento de propostas políticas e modelos de comportamento autoritários.

Vale dizer que, com todas as guerras, processos de repressão e exploração, genocídios e tudo de ruim que a civilização ocidental experimentou do século XIX até hoje, não se pode descartar inteiramente suas conquistas. A civilização ocidental produziu na modernidade imensos avanços, do campo tecnológico e científico ao político, ético, moral e jurídico. Trata-se do único modelo civilizatório capaz de fazer a autocrítica de seus processos de violência, como o nazismo e o fascismo, os genocídios etc. 
Aparentemente, também têm contribuído para o aniquilamento do nosso common ground humanista certos aspectos fundamentais desse processo que, como todo engenho humano, têm características negativas, como é o caso da comunicação por internet. Esse ambiente, que permite enorme facilidade na pesquisa, no acesso a documentos, estudos e informações que favorecem o desenvolvimento cultural, também é o espaço - as redes sociais, em especial - da produção de dois fenômenos interessantes e ao mesmo tempo assustadores: o conhecimento superficial e a expressão das emoções sem qualquer tipo de pudor, de freio civilizatório.

Se a internet propicia algum nível de informação, o principal problema daqueles que se digladiam, ao contrário do que se costuma dizer, não é a ignorância, mas o conhecimento raso e fragmentado acerca dos fenômenos. Basta um conhecimento superficial de um determinado tema ou acontecimento para fazer com que se sintam aptos a avalizar um determinado ponto de vista.

Acontece que, como bem pontuou Hannah Arendt, o mal sobrevive na banalidade, na superficialidade, nunca é radical, pois não desce à raiz, não tem profundidade. Mas pode ser extremo. Agentes policiais torturam prisioneiros por acreditarem de forma irrefletida que isso faz parte do seu papel profissional. É a ausência de reflexão - ética, moral, política - a origem do mal que pode se tornar extremo e levar a um genocídio.

Essa mesma falta de reflexão, conjugada à ausência de qualquer freio civilizatório, tem pautado diariamente o debate público e, principalmente, as discussões que se estabelecem nas redes sociais.

Não se pode interpretar democracia apenas como um espaço onde é possível divergir, assim como não se pode imaginar o ambiente da política, numa democracia, como o ambiente das emoções mais primitivas. Democracia pressupõe consensos formados pelos debates dotados de um mínimo de profundidade analítica e reflexiva, onde a racionalidade e a moral humanista sirvam de freio sublimatório dos afetos mais primitivos. Rubens Casara nos sugere um caminho:

Um dos caminhos para responder à emergência do Estado Pós-Democrático passa por abandonar o culto à ação sem reflexão, os estereótipos e as visões reducionistas do mundo que fazem com que conservadores se apresentem como 'liberais,' 'marxistas', defendam a perda do valor do trabalho e 'feministas' sustentem posições de poder repressivas e bélicas atreladas a concepções hierarquizadas e essencialistas originadas do patriarcado. O desejo de democracia, ligado à concretização dos direitos, exige atenção ao imaginário. Construir a democracia, inclusive no Sistema de Justiça, é superar o imaginário autoritário. ${ }^{49}$

49 CASARA, Rubens R. R. Estado pós-democrático: neo-obscurantismo e gestão dos indesejáveis. Rio de Janeiro: Civilização Brasileira, 2017, p. 84. 


\section{REFERÊNCIAS}

AGAMBEM, Giorgio. Estado de exceção. Tradução de Iraci D. Poleti. 2. ed. São Paulo: Boitempo, 2011.

ARENDT, Hannah. Origens do totalitarismo. Trad. Roberto Raposo. São Paulo: Companhia das Letras, 1989.

BACK, Charlotth. Direito penal do inimigo político. In: PRONER, Carol; CITTADINO, Gisele; RICOBOM, Gisele; DORNELLES, João Ricardo (Org.). Comentários a uma sentença anunciada: o processo Lula. Bauru: Canal 6, 2017. p. 91-95.

BOBBIO, Norberto. Contra os novos despotismos: escritos sobre o berlusconismo. São Paulo: Editora Unesp; Instituto Norberto Bobbio, 2016.

CASARA, Rubens R. R. Estado pós-democrático: neo-obscurantismo e gestão dos indesejáveis. Rio de Janeiro: Civilização Brasileira, 2017.

DWORKIN, Ronald M. Is democracy possible here? : Principles for a new political debate. New Jersey: Princeton University Press, 2008.

DUNLAP, JR., Charles J. Law and Military Interventions: Preserving Humanitarian Values in 21st Conflicts. Humanitarian Challenges in Military Intervention Conference Carr Center for Human Rights Policy. Washington, D.C: Kennedy School of Government, Harvard University, 2001

FERRAJOLI, Luigi. Poderes Selvagens: a crise da democracia italiana. São Paulo: Saraiva, 2014.

LACERDA, Fernando Hideo I. A caçada de Lula pelo processo penal de exceção na era da pós-verdade. In: PRONER, Carol; CITTADINO, Gisele; RICOBOM, Gisele; DORNELLES, João Ricardo (Org.). Comentários a uma sentença anunciada: o processo Lula. Bauru: Canal 6, 2017. p. 141-145.

MBEMBE, Achille. Crítica da razão negra. Trad. Marta Lança. Lisboa: Antígona, 2014.

SANTOS, Boaventura de Sousa. A difícil democracia. São Paulo: Boitempo, 2016.

SERRANO, Pedro Estevam Alves Pinto. Autoritarismo e golpes na América Latina: breve ensaio sobre jurisdição e exceção. São Paulo: Alameda, 2016.

TEIXEIRA, Alessandra. Prisões da exceção: política penal e penitenciária no Brasil contemporâneo. Curitiba: Juruá, 2009.

VALIM, Rafael. Estado de exceção: a forma jurídica do neoliberalismo. São Paulo: Editora Contracorrente, 2017.

VALIM, Rafael. O princípio da segurança jurídica no direito administrativo brasileiro. São Paulo: Malheiros, 2010. 